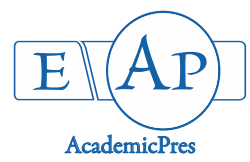

\title{
Antimicrobial Activity of Olea europaea Fatty Oil against Multi-Drug Resistant and Biofilm Forming Microorganisms
}

\author{
Haifaa Bawie NAJEE ${ }^{1,2}$, Dunya ALKURJIA ${ }^{1}$, Othman ALMAHDAWY ${ }^{1,2}$, \\ Crina KAMERZAN ${ }^{2}$, Luminita MARUTESCU ${ }^{1,2 *}$ Irina GHEORGHE ${ }^{1,2}$, \\ Marcela POPA ${ }^{1,2}$, Mariana Carmen CHIFIRIUC ${ }^{1,2}$, Veronica LAZĂR ${ }^{1,2}$ \\ ${ }^{1}$ University of Bucharest, Faculty of Biology, Department of Botany-Microbiology, Bucharest; \\ Romania; haifaabio84@gmail.com; donia_life@yahoo.com; othman51@gmail.com;lumi.marutescu@gmail.com; iryna_84@yahoo.com; \\ carmen.chifiriuc@gmail.com; bmarcelica@yahoo.com; veronica.lazar2009@gmail.com \\ ${ }^{2}$ Research Institute of the University of Bucharest-ICUB, Bucharest, \\ Romania; crina.saviuc@yahoo.com; lumi.marutescu@gmail.com ("correspondingauthor)
}

\begin{abstract}
The aim of the present study was to investigate the potential antimicrobial activity of Olea europaea fatty oil against a collection of bacterial (Staphylococcus aureus, Escherichia coli and Pseudomonas aeruginosa) and fungal (Candida albicans) clinical isolates. The antimicrobial and antibiofilm activity were evaluated by broth microdilution method for establishing the minimal inhibitory concentration (MIC) and microtiter assay for determining the minimal biofilm eradication concentration (MBEC). Some of the potential microbial targets of the fatty oil were investigated by flow cytometry (FCM). The results obtained hereby revealed that Olea europaea fatty oil inhibited microbial planktonic growth (MICs values of 5.23-41.8 mg/ $\mathrm{mL}$ ) and biofilm development on inert substrata (MBEC values of 1.31-20.9 mg/ mL). The FCM measurements confirmed that the analyzed oil induced microbial membrane damages and inhibited microbial efflux pump activity.
\end{abstract}

Keywords: antimicrobial activity; anti-biofilm activity; efflux pump; fatty oil; flow cytometry

\section{Introduction}

Nowadays, microbial resistance is recognized as a top 5 priority worldwide problem (Perveen et al., 2012), generating an acute need for searching new antimicrobial agents. The use of medicinal plants for the treatment of diseases dates back to the history of human life, that is, since human beings have sought a tool into environment for combating diseases (Halberstein, 2005). Pseudomonas aeruginosa, Staphylococcus aureus and Candida albicans are opportunistic nosocomial pathogens responsible for a wide range of acute or chronic infections (Telcian et al., 2017). Evidence shows that medicinal plants have been cultivated approximately 60000 years ago (Solecki and Shanidar, 1975). Scripts about medicinal plants date back to about 5000 years ago in China, India, Egypt, and at least 2500 years in Greece and Central Asia (Ang-Lee et al., 2001). Almost $80 \%$ of the people around the world have used herbal plants in primary health care (Mehrotra and Srivastava, 2010). Herbal drugs could represent promising solutions for fighting antibiotic resistant infections (Rahman and Hossain, 2010). Many researchers have investigated the antimicrobial properties of several vegetal active compounds obtained from spices, herbs and extracted oils (Burt, 2004; Proestos et al., 2005), some of the most studied being the phenolic compounds, which are components of plant defense mechanisms against microbial pathogens (Pereira, 2007; Slobodníková et al., 2016), such as thymol, catechins, carvacrol, chlorogenic acid, oleuropein and cinnamaldehyde (Friedman et al., 2006; Almeida et al., 2006). In the present study, the purposes were to investigate the antimicrobial and anti-biofilm activities of Olea europaea fatty oil. At the end of the sixties the researchers began to correlate the antimicrobial activity of olive oil to the phenolic compounds (Fleming and Etchells, 1967; Zanichelli et al., 2005; Pereira, 2007). The major phenolic compound in olive fruits is oleuropein, a bitter glucoside composed of glucose, polyphenol hydroxytyrosol and elenolic acid. 
Antimicrobial inhibitory effects are more pronounced in case of virgin olive oils, followed by olive oils and pomace olive oils, which is in accordance with their decreasing content in phenolic compounds. The olive oils were demonstrated to possess antimicrobial activity against a wide range of Gram-positive and Gram-negative bacteria, including Staphylococcus aureus, Listeria monocytogenes, Clostridium perfringens, Lactobacillus acidophilus, Bifidobacterium bifidum, Escherichia coli, Salmonella enterica, Yersinia sp., Shigella sonnei (Medina et al., 2006). The studies revealed that Gram-positive bacteria are more susceptible to olive oil polyphenols than Gram-negative ones, mainly due to differences in the cell wall structure and to the presence of an additional layer represented by the outer membrane in Gram-negative bacteria, which can act as a barrier towards macromolecules penetration (Nikaido, 1996). Spanish virgin olive oils were demonstrated to possess antimicrobial activity against Helicobacter pylori strains (Romero et al., 2007). Also, the extract of olive leaf exhibited growth inhibition ability against Candida albicans (Markin et al., 2003). The main antimicrobial mechanisms described for phenolic compounds include plasma membrane damage, interference with cell wall synthesis, reduction of membrane fluidity, inhibition of nucleic acid synthesis (Gyawali and Ibrahim, 2014). Antibiofilm activity was correlated with the ability of phenolic compounds to affect the bacterial regulatory mechanisms such as quorum sensing or other global regulator systems (Silva et al., 2016). The aim of the study was to investigate the potential antimicrobial activity of Olea europaea fatty oil against multi-drug resistant (MDR) microorganisms.

\section{Materials and Methods}

\section{Microbialstrains}

A collection of 43 clinical microbial strains belonging to different species of bacteria (Escherichia coli, Pseudomonas aeruginosa and Staphylococcus aureus) and fungi (Candida albicans) were included in the present study. They were isolated form patients admitted to "Prof. C. C. Iliescu" Institute of Cardiovascular Diseases, Bucharest, Romania, Fundeni Hospital and identified at species level using Vitek II. The isolates were maintained in the laboratory on TSA (Tryptone Soy Agar) medium.

\section{Broth microdilution assay}

The antimicrobial activity of the commercial Olea europaea fatty oil (Salvadori, Italy) was investigated by broth microdilution assay carried out in 96 multi wells plates (Saviuc et al., 2011). The plant fatty oil was solubilized in dimethylsulfoxide (DMSO) in 1:1 ratio (v/v). Serial twofold dilutions were prepared in Luria Broth broth starting with $41.8 \mathrm{mg} / \mathrm{mL}$ to $0.08 \mathrm{mg} / \mathrm{mL}$. Then the wells containing different concentrations of the tested fatty oil were inoculated with microbial suspensions $\left(1.5 \times 10^{8}\right.$ $\mathrm{cfu} / \mathrm{ml}$ ) prepared from 18-24 h solid cultures. Negative controls, represented by uninoculated broth and positive controls represented by untreated bacterial cultures were included for each of the tested microbial strain. Additionally, the solubilizing agent, DMSO, was also examined for antimicrobial activity. After incubation at $37^{\circ} \mathrm{C}$ for $24 \mathrm{~h}$, the minimal inhibitory concentrations (MICs) values of the fatty oil against the microbial isolates were assessed by measuring the optical density at $620 \mathrm{~nm}$ (EZ Read 400, Bichrom). All experiments were carried out in triplicate.

Evaluation of the potential antibiofilm activity of Olea europaea fatty oil

The influence of Olea europaea fatty oil on biofilm development at inert substratum was evaluated by microtiter method. The microbial cultures exposed to different concentrations of fatty oil in 96 well plates were discarded after 24 hours of incubation at $37^{\circ} \mathrm{C}$. The wells were washed gently three times with PBS. The remaining, well adherent microbial cells were then fixed with cold methanol for 5 minutes and colored with $1 \%$ crystal violet for 20 minutes at room temperature. The wells were gently washed three times with tap water and the resulting colored biofilms were resuspended by adding 33\% acetic acid. The colored suspensions were quantified spectrophotometrically at $492 \mathrm{~nm}$ (EZ Read 400 reader, Bichrom) to establish the minimal biofilm eradication concentration (MBEC). The experiments were performed in triplicate.

Flow cytometric (FCM) assay for detection of plant EOs antimicrobial action mechanisms

The tested microbial strains treated with olive oil at $1 / 2$ $\times$ MIC were analyzed by FCM, using the acid nucleic intercalating dyes: propidium iodide (PI) and ethidium bromide (EB). The dyes do not penetrate and accumulate inside viable cells, therefore the fluorescence (median fluorescence intensity (MFI)) measured in channel 2 (ethidium bromide) and respectively in channel 3 (propidium iodide) is low. If the microbial cell wall is affected (loss of integrity / affected efflux pump activity), the dyes enters the cell and bind to nucleic acid, resulting in an increased fluorescence.

Samples were stained at room temperature with 10 $\mu \mathrm{L} / \mathrm{ml}$ for PI and $5 \mu \mathrm{g} / \mathrm{mL}$ EB, in the dark, for 10 minutes. The fluorescence measurements were performed using the FACSCalibur flow cytometer (BD, Sparks, USA) equipped with an argon laser with an excitation wavelength of 488 $\mathrm{nm}$. For each sample, a total of 10,000-30,000 events were acquired. CellQuest Pro software was used for statistical analysis. Microbial populations were gated based on the FSC / SSC characteristics.

\section{The antimicrobial activity of olive oil}

Antimicrobial resistance emerged as a result of overuse and inappropriate use of antibiotics in the treatment of infectious diseases. The high resistance rates are threating the efficiency of the current treatment strategies and encourage us to search novel strategies to combat increasing MDR organisms (Llor and Bjerrum, 2014). Since ancient times, plants extracts are known to possess antimicrobial properties being used in the treatment of different diseases. In this context, we investigated the potential antimicrobial activity of $O$. europaea oil against a collection of pathogenic bacteria and fungi. Broth microdilution assays showed that O. europaea oil exhibited a variable antimicrobial activity 
500

against the tested isolates, with MIC values ranging from $5.23 \mathrm{mg} / \mathrm{ml}$ to $>41.8 \mathrm{mg} / \mathrm{ml}$. O. europaea oil was more active against $S$. aureus isolates (Table 1). The least susceptible microorganism was $P$. aeruginosa, the resistance of this bacterium to a wide range of natural and synthetic antimicrobials being partly due to its hydrophilic outer membrane and exopolysaccharidic capsule. Different geographical conditions (Ronalli, 2006) and the method of preparation influence the content of antimicrobial components present in the extracts. Janakat $e t$ al. (2015) found that MIC and minimum bactericidal concentration (MBC) of olive oil leaves ranged from 60 to $80 \mu \mathrm{l} / \mathrm{ml}$. Pereira et al. (2007) found the MICs of a Portuguese table olive extract against many Gram-positive and Gramnegative bacterial strains, ranged from 10 to $100 \mu \mathrm{l} / \mathrm{ml}$ at 37 ${ }^{\circ} \mathrm{C}$. The results of the study of Sudjana $\mathrm{et} \mathrm{al}$. (2009) revealed that the MICs of commercial extract derived from the leaves of Olea europaea against Campylobacter jejuni, Helicobacter pylori and Staphylococcus aureus [including meticillin-resistant $S$. aureus (MRSA) were as low as 0.31$0.78 \%(\mathrm{v} / \mathrm{v})$. In contrast, the extract showed little activity against many other tested organisms, with MICs for most ranging from $6.25 \%$ to $50 \%(\mathrm{v} / \mathrm{v})$. The antibacterial activity of olive oil is due to the phenolic compounds, which can induce damages of the bacterial membrane and disrupt the cell wall peptidoglycan, causing the loss of structural solidity and leakage of intracellular cytoplasmic components (Caturla et al., 2005). Furthermore, the hydroxyl group in phenolic compounds can bind to the active sites of enzymes, changing their substrate affinity. Additionally, the lipid solubility and the degree of steric hindrance they may cause contribute to their overall antimicrobial activity (Ceylan and Fung, 2004).

O. europaea oil activity on microbial adhesion to inert substrata

Biofilm-associated infections accounting for up to $80 \%$ of the total number of human infections (Fleming and Rumbaugh, 2017) are considered a big challenge to the medical community, as antibiotic tolerance is more than 1000-fold increase in biofilm embedded pathogens (Rogers et al., 2010); moreover, the biofilm also protects microbial

Table 1 . MIC values $(\mathrm{mg} / \mathrm{ml})$ of the tested fatty oil

\begin{tabular}{cc}
\hline Microbial strains & $\begin{array}{c}\text { O. europaea } \\
\min -\max \end{array}$ \\
\hline E.coli $(\mathrm{n}=7)$ & $20.9-41.8$ \\
P. aeruginosa $(\mathrm{n}=10)$ & 41.8 \\
S. aureus $(\mathrm{n}=10)$ & $5.23->41.8$ \\
C. albicans $(\mathrm{n}=16)$ & $10.45->41.8$ \\
\hline
\end{tabular}

Table 2. MBEC values $(\mathrm{mg} / \mathrm{ml})$

\begin{tabular}{cc}
\hline Microbial strains & $\begin{array}{c}\text { O. europaea } \\
\min -\max \end{array}$ \\
\hline E. coli $(\mathrm{n}=7)$ & $5.23-20.9$ \\
P. aeruginosa $(\mathrm{n}=10)$ & $10.45->41.8$ \\
S. aureus $(\mathrm{n}=10)$ & $1.31->41.8$ \\
C. albicans $(\mathrm{n}=16)$ & $2.61->41.8$ \\
\hline
\end{tabular}

cells from the host immune response). The study of Slobodníková et al. (2016) revealed that the phenolic compounds are also very active against biofilm embedded bacteria.

Regarding the antibiofilm activity, the results indicated that the O. europaea oil was able to inhibit adherence of the microbial cells at inert substrate at $1 / 2 \times$ MIC. Inhibition of biofilm formation was detected at concentrations ranging from $1.31 \mathrm{mg} / \mathrm{ml}$ (S. aureus) to $>41.8 \mathrm{mg} / \mathrm{ml}(P$. aerugionsa, C. albicans). The antimicrobial and antibiofilm activities of the tested oil could be attributed to the high amounts (73.41\%) of the phenolic compound oleuropein present in O. europaea oil (Pereira, 2007).

Investigation of some of the possible mechanisms of the antimicrobial activity of $O$. europaea oil by flow cytometry

The possible mechanisms of the antimicrobial action of vegetal oils were previously reported to be the membrane damage potential and efflux pumps inhibitor (EPI) activity (Gellatly and Hancock, 2013). In our study, microbial cells exposed to $O$. europaea oil, at $1 / 2 \times$ MIC exhibited an increased fluorescence after staining with PI and EB, respectively. The MFI of the treated cells was significantly higher than the MFI of the controls (two-fold or higher values than of viable control cells) (Table 3) suggesting an increase in the fraction of microbial cells with permeabilized cell envelope, at 1/2 $\times$ MIC. The PI and EB dyes were able to enter the permeabilized cells, bind nucleic acids resulting in an enhanced fluorescence of the cells. Therefore, the FCM results confirm that one of the mechanisms by which the $O$. europaea oil extert its antimicrobial activity is represented by inducing damages to the microbial cell wall. This mechanism was detected in all tested microbial isolates. Engel (2003), Martins et al. (2013) proposed a relation between the fluorescence intensity (FI) of the cells labeled with $\mathrm{EB}$ and the ratio net influx of $\mathrm{EB} / \mathrm{EB}$ extracellular ejection via the efflux pump activity ratio (Martins et al., 2013) (Figs. 1-2).

Table 3. The values of MFI for PI stained microbial cells exposed to O. europaea oil at $1 / 2 \times \mathrm{MIC}$

\begin{tabular}{cccc}
\hline $\begin{array}{c}\text { Plant EOs } \\
\text { Microbial strains }\end{array}$ & $\begin{array}{c}\text { O. europaea } \\
(\mathrm{n}=\text { number of } \\
\text { isolates })\end{array}$ & $\begin{array}{c}\text { Viable cells } \\
\text { control }\end{array}$ & $\begin{array}{c}\text { Dead cells } \\
\text { control }\end{array}$ \\
\hline C. albicans & $\begin{array}{c}16.14 \\
(\mathrm{n}=5)\end{array}$ & 6.78 & 323.57 \\
E. coli & $\begin{array}{l}10.46 \\
(\mathrm{n}=1)\end{array}$ & 4.53 & 15.68 \\
P. aeruginosa & $\begin{array}{l}14.41 \\
(\mathrm{n}=5)\end{array}$ & 4.53 & 15.68 \\
\hline
\end{tabular}

Table 4. The values of MFI for EB stained microbial cells exposed to O. europaea oil at $1 / 2 \times$ MIC

\begin{tabular}{cccc}
\hline $\begin{array}{c}\text { Plant EOs } \\
\text { Microbial strains }\end{array}$ & $\begin{array}{c}\text { O. europaea } \\
(\mathrm{n}=\text { number of } \\
\text { isolates })\end{array}$ & $\begin{array}{c}\text { Viable cells } \\
\text { control }\end{array}$ & $\begin{array}{c}\text { Dead cells } \\
\text { control }\end{array}$ \\
\hline C. albicans & $\begin{array}{c}31.92 \\
(\mathrm{n}=11)\end{array}$ & 6.78 & 323.57 \\
E. coli & $\begin{array}{c}36.84 \\
(\mathrm{n}=3)\end{array}$ & 4.53 & 24.62 \\
P. aeruginosa & $\begin{array}{c}20 \\
(\mathrm{n}=2)\end{array}$ & 4.53 & 24.62 \\
\hline
\end{tabular}




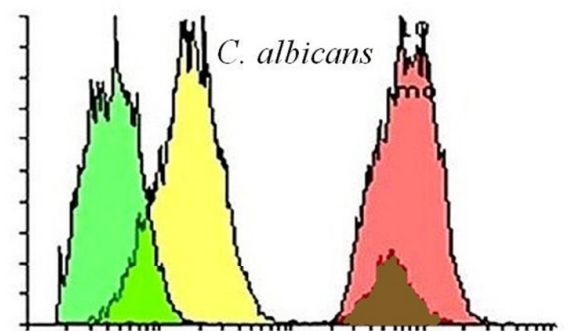

FL2-H

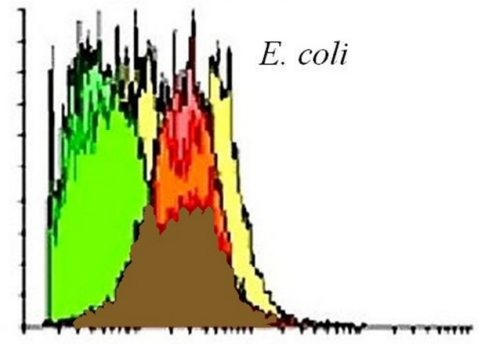

FL2-H

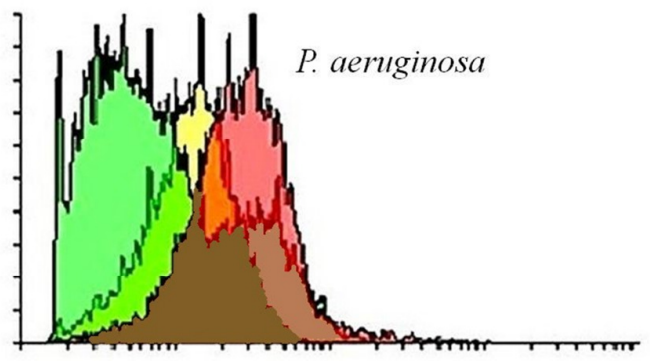

FL2-H

Fig. 1. Overlay of the histogram for the median of the fluorescence intensity of efflux pumps, viable cells control (green) and heat treated cells control (red), cells treated with O. europaea fatty oil (yellow); a, b, c - typical aspects of the histograms obtained at $\mathrm{MIC} / 2$ concentration values for tested bacteria

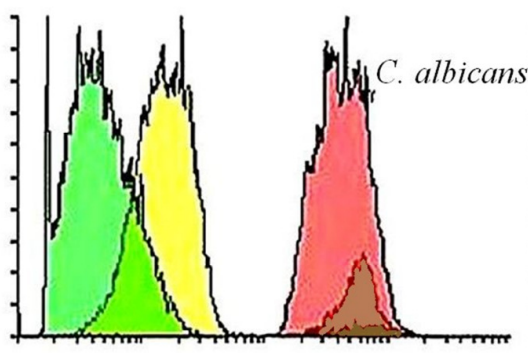

FL3-H

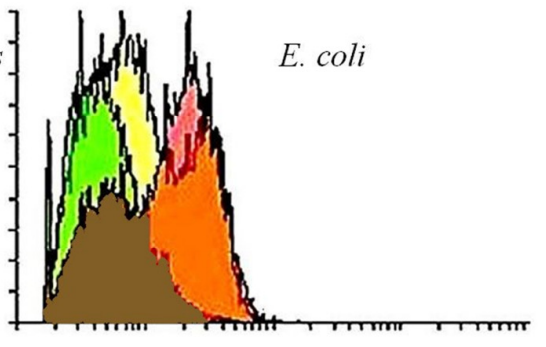

FL3-H

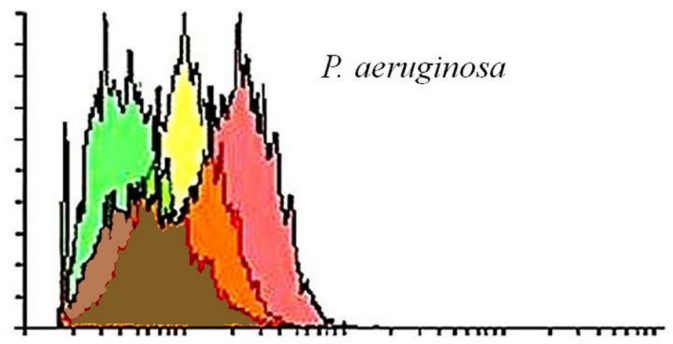

FL3-H

Fig. 2. Overlay of the histogram for the median of the fluorescence intensity of cell membrane integrity, viable cells control (green) and heat treated cells control (red), cells treated with $O$. europaea fatty oil (yellow); a, b, c, d - typical aspects of the histograms obtained at MIC/2 concentration values for C. albicans, E. coli, P. aeruginosa, $S$. aureus, respectively

\section{Conclusions}

The investigation of the influence of $O$. europaea fatty oil on drug resistant bacterial and fungal strains growth has shown that the tested oil has been active against planktonic and biofilm embedded cells, by actively interacting with microbial surface structures essential for growth and survival, such as membrane and efflux pumps. These results are demonstrating the potential of $O$. europaea as a source of bioactive antimicrobial compounds for controlling antibiotic resistant pathogens. However, for drug development additional tests are needed to determine their toxicity and pharmacokinetic and pharmacodynamic properties. 
502

\section{Acknowledgements}

The financial support of PN-III-P2-2.1-BG-2016-0369 research project granted by the Executive Unit for Financing Higher Education, Research, Development and Innovation (UEFISCDI) is gratefully acknowledged.

\section{References}

Almeida AAP, Farah A, Silva DA, Nunan EA, Glória MBA (2006). Antibacterial activity of coffee extracts and selected coffee chemical compounds against enterobacteria. Journal of Agricultural and Food Chemistry 54:8738-8743.

Ang-Lee MK, Moss J, Yuan CS (2001). Herbal medicines and perioperative care.JAMA286(2):208-216.

Burt S (2004). Essential oils: their antibacterial properties and potential applications in foods-a review. International Journal of Food Microbiology 94:223-253.

Caturla N, Pérez-Fons L, Estepa A, Micol V (2005). Differential effects of oleuropein, a biophenol from Olea europaea, on anionic and zwiterionic phospholipid model membranes. Chemistry and Physics of Lipids 137(1-2):2-17.

Ceylan E, Fung DYC (2004). Antimicrobial activity of spices. Journal of Rapid Methods and Automation in Microbiology 12(1):1-55.

Engel J (2003). Molecular pathogenesis of acute Pseudomonas aeruginosa infections. In: Hauser AR, Rello J (Eds). Severe Infections Caused by Pseudomonas aeruginosa. Springer Science, Business Media, LLC: New York,NY,USA pp201-218.

Fleming D, Rumbaugh KP (2017). Approaches to dispersing medical biofilms. Microorganisms 5(2):15.

Fleming H, Etchells J (1967). Occurrence of an inhibitor of lactic acid bacteriain green olives. Applied Microbiology 15:1178-1184.

Friedman M, Henika PR, Levin CE, Mandrell RE, Kozukue N (2006). Antimicrobial activities of tea catechins and theaflavins and tea extracts against Bacilluscereus. Journal of Food Protection 69:354361.

Gellatly SL, Hancock RE (2013). Pseudomonas aeruginosa: New insights into pathogenesis and host defenses. Pathogens andDisease 67(3):159-173.

Gyawali R, Ibrahim SA (2014). Natural products as antimicrobial agents. Food Control 46:412-429.

Halberstein RA (2005). Medicinal plants: historical and cross-cultural usage patterns. Annals of Epidemiology 15(9):686-99.

Janakat S, Alnabulsi AA, Allehdan S, Holley RA (2015). Antimicrobial activity of amurca (olive oil lees) extract against selected foodborne pathogens. Food Science and Technology35(2):259-265.

Llor C, Bjerrum L (2014). Antimicrobial resistance: risk associated with antibiotic overuse and initiatives to reduce the problem. Therapeutic Advances in DrugSafety 5(6):229-241.

Markin D, Duek L, Berdicevsky I (2003). In vitro antimicrobial activity of olive leaves. Mycoses 46:132-136.

Martins M, McCusker MP, Viveiros M, Couto I, Fanning S, Pagès J-M, Amaral L (2013). A simple method for assessment of MDR bacteria for over-expressed efflux pumps. The Open Microbiology Journal 7:72-82.

Medina E, De Castro A, Romero C, Brenes M (2006). Comparison of the concentrations of phenolic compounds in olive oils and other plant oils: correlation with antimicrobial activity. Journal of Agricultural and Food Chemistry 54:49544961.

Mehrotra S, Srivastava AK (2010). Comparative antimicrobial activities of Neem, Amla, Aloe, Assam Tea and Clove extracts against Vibrio cholerae, Staphylococcus aureus and Pseudomonas aeruginosa. Journal of Medicinal Plants Research 4(23):2473-2478.

Nikaido H (1996). Escherichia coli and Salmonella. In: Neidhart FC (Ed). Cellular and Molecular Biology. ASM Press, Washington DC pp 2947.

Pereira JA (2007). Phenolic compounds and antimicrobial activity of olive (Olea europaea L. Cv. Cobrançosa) leaves. Molecules 12(5):1153-1162.

Perveen K, Bokhari NA, Soliman DA (2012). Antibacterial activity of Phoenix dactylifera L. leaf and pit extracts against selected Gram negative and Gram positive pathogenic bacteria. Journal of Medicinal Plants Research 6(2):296-300.

Proestos C, Chorianopoulos N, Nychas GJ, Komaitis M (2005). RPHPLC analysis of the phenolic compounds of plant extracts. Investigation of their antioxidant capacity and antimicrobial activity. Journal of Agricultural and Food Chemistry 53(4):1190-1195.

Rahman MM, Hossain MN (2010). Antibiotic and herbal sensitivity of some Aeromonas sp. isolates collected from diseased carp fishes. Progressive Agriculture 21(1-2):117-129.

Rogers SA, Huigens RW, Cavanagh J, Melander C (2010). Synergistic effects between conventional antibiotics and 2-aminoimidazole-derived antibiofilm agents. Antimicrobial Agents Chemotherapy 54(5):21122118.

Romero C, Medina E, Vargas J, Brenes M, De Castro A (2007). In vitro activity of olive oil polyphenols against Helicobacter pylori. Journal of Agricultural and Food Chemistry 55(3):680-686.

Ronalli A, Contento S, Lucera L, Di Febo M, Marchegiani D, Di Fonzo V (2006). Factors affecting the content of iridoid oleuropein in olive leaves (Olea europea L.). Journal of Agriculture and Food Chemistry 54(2):434440.

Saviuc C, Grumezescu AM, Oprea E, Radulescu V, Dascalu L, Chifiriuc MC, Bucur M, et al., Lazar V (2011). Antifungal activity of some vegetal extracts on Candida biofilms developed on inert substratum. Biointerface Research in Applied Chemistry 1(1):15-23.

Silva LN, Zimmer KR, Macedo AJ, Trentin DS (2016). Plant natural products targeting bacterial virulence factors. Chemical Reviews 116(16):9162-9236.

Slobodníková L, Fialová S, Rendeková K, Kováč J, Mučaji P (2016). Antibiofilm activity of plant polyphenols. Molecules 21(12):1717.

Solecki R, Shanidar IV (1975). A Neanderthal flower burial in Northern Iraq. Science 190(4217):880-881.

Sudjana AN, D'Orazio C, Ryan V, Rasool N, Ng J, Islam N, Riley, et al, Hammer KA (2009). Antimicrobial activity of commercial Olea europaea (olive) leaf extract. International Journal of Antimicrobial Agents 3(5):461-463.

Telcian A, Mohammed DH, Chifiriuc MC, Bleotu C, Holban AM, Curutiu C, et al., Ditu LM (2017). Assessment of the anti-biofilm activity and biocompatibility of novel PE and PVC polymers. Romanian Biotechnological Letters 22(50):12997-13004.

Zanichelli D, Baker TA, Clifford MN, Adams MR (2005). Inhibition of Staphylococcus aureus by oleuropein is mediated by hydrogen peroxide. Journal of Food Protection 68(7):1492-1496. 